\title{
Effect of micro-environment in ridge and southern slope on soil respiration in Quercus mongolica forest
}

\author{
Jae-Seok Lee(i)
}

\begin{abstract}
Background: Soil respiration (Rs) is a major factor of the absorption and accumulation of carbon through photosynthesis in the ecosystem carbon cycle. This directly affects the amount of net ecosystem productivity, which affects the stability and sustainability of the ecosystem. Understanding the characteristics of Rs is indispensable to scientifically understand the carbon cycle of ecosystems. It is very important to study Rs characteristics through analysis of environmental factors closely related to Rs. Rs is affected by various environmental factors, such as temperature, precipitation, soil moisture, litter supply, organic matter content, dominant plant species, and soil disturbance. This study was conducted to analyze the effects of micro-topographical differences on Rs in forest vegetation by measuring the Rs on the ridge and southern slope sites of the broadly established Quercus mongolica forest in the central Korean area.

Method: Rs, Ts, and soil moisture data were collected at the southern slope and ridge of the Q. mongolica forest in the Mt. Jeombong area in order to investigate the effects of topographical differences on Rs. Rs was collected by the closed chamber method, and data collection was performed from May 2011 to October 2013, except Winter seasons from November to April or May. For collecting the raw data of Rs in the field, acrylic collars were placed at the ridge and southern slope of the forest. The accumulated surface litter and the soil organic matter content (SOMC) were measured to a $5 \mathrm{~cm}$ depth. Based on these data, the Rs characteristics of the slope and ridge were analyzed.
\end{abstract}

Results: Rs showed a distinct seasonal variation pattern in both the ridge and southern slope sites. In addition, Rs showed a distinct seasonal variation with high and low Ts changes. The average Rs measurements for the two sites, except for the Winter periods that were not measured, were $550.1 \mathrm{mg} \mathrm{CO}_{2} \mathrm{~m}^{-2} \mathrm{~h}^{-1}$ at the ridge site and $289.4 \mathrm{mg} \mathrm{CO}_{2} \mathrm{~m}^{-2} \mathrm{~h}^{-1}$ at the southern slope, a difference of 52.6\%. There was no significant difference in the Rs difference between slopes except for the first half of 2013, and both sites showed a tendency to increase exponentially as Ts increased. In addition, although the correlation is low, the difference in Rs between sites tended to increase as Ts increased. SMC showed a large fluctuation at the southern slope site relative to the ridge site, as while it was very low in 2013, it was high in 2011 and 2012. The accumulated litter of the soil surface and the SOMC at the depth range of $0 \sim 5 \mathrm{~cm}$ were $874 \mathrm{~g} \mathrm{~m}^{-2}$ and $23.3 \%$ at the ridge site, and $396 \mathrm{~g} \mathrm{~m}^{-2}$ and $19.9 \%$ at the southern slope site.

(c) The Author(s). 2018 Open Access This article is distributed under the terms of the Creative Commons Attribution 4.0 International License (http://creativecommons.org/licenses/by/4.0/), which permits unrestricted use, distribution, and reproduction in any medium, provided you give appropriate credit to the original author(s) and the source, provide a link to the Creative Commons license, and indicate if changes were made. The Creative Commons Public Domain Dedication waiver (http://creativecommons.org/publicdomain/zero/1.0/) applies to the data made available in this article, unless otherwise stated. 


\begin{abstract}
(Continued from previous page)
Conclusions: In this study, Rs was measured for the ridge and southern slope sites, which have two different results where the surface litter layer is disturbed by strong winds. The southern slope site shows that the litter layer formed in autumn due to strong winds almost disappeared, and while in the ridge site, it became thick due to the transfer of litter from the southern slope site. The mean Rs was about two times higher in the ridge site compared to that in the southern slope site. The Rs difference seems to be due to the difference in the amount of litter accumulated on the soil surface. As a result, the litter layer supplied to the soil surface is disturbed due to the micro-topographical difference, as the slope and the change of the community structure due to the plant season cause heterogeneity of the litter layer development, which in turn affects SMC and Rs. Therefore, it is necessary to introduce and understand these micro-topographical features and mechanisms when quantifying and analyzing the Rs of an ecosystem.
\end{abstract}

Keywords: Soil respiration, Ridge and southern slops, Forest ecosystem, Accumulated litter

\section{Background}

In the ecosystem carbon cycle, carbon stored in soil is released to the atmosphere through plant roots and microbial soil respiration (Rs). Because Rs is closely related to vegetation, soil temperature (Ts), precipitation, soil moisture, and so on, quantifying and calculating carbon emissions from the soil to the atmosphere requires a detailed understanding of the interrelationships between these regulatory factors and Rs. Many studies have reported that Rs varies according to the dominant species of an ecosystem (Schlesinger 1977; Singh and Gupta 1977; Raich and Schlesinger 1992; Raich and Tufekcloglu 2000), and showed differences of varying vegetation (Joo et al. 2012; Chae 2011; Jeong et al. 2018; Eom et al. 2018). This difference is caused by effect of vegetation on the type, quantity, Ts, and moisture content of soil organic matter, which is the material that causes microbial soil respiration.

It is known that Ts, soil moisture, and organic matter content play a major role in Rs changes (Lloyd and Taylor 1994; Raich and Potter 1995). Among these factors, the most important factor affecting the Rs is the Ts, which is mainly a factor controlling the season and day change of Rs. The second most important is soil moisture, which affects soil roots, microbial activity, and soil physiochemical properties (Raich and Schlesinger 1992; Davidson et al. 1998; Liu et al. 2002).

However, this temperature factor can also be affected by variation in Rs rates based on two primary factors: the amount of root biomass in the soil and the amount of soil organic matter content (SOMC). As distance from the tree increases, root biomass and Rs values are shown to strongly decrease exponentially, and root biomass increases logarithmically with increases in Rs. In addition, Rs and underground root biomass are logarithmically related; the calculated root-breathing rate was around $44 \%$. These changes in plant root mass greatly affect the Rs rate (Maier and Kress 2000; Luo et al. 1996; Lee 2018).

Microbial respiration in Rs is caused by the secretion of organic soil matter and by soil carbon from litter-derived organic matter and roots, supplied from both above and below, and depends on the quality and amount of organic matter supplied to the forest (Son and Kim 1996). The distribution of roots also influences the Rs by changing the distribution of soil organic matter (Lee 2018).

Rs is also affected by the topographical characteristics of the study area (Kang et al. 2003). Micro-topographical features are related to spatial diversity and are caused by the complexity of the terrain (Ohashi and Gyokusen 2007). Topographical factors are linked to other factors influencing Ts, moisture content, and litter accumulation closely related to Rs.

In this study area, the canopy is open from autumn to spring, and strong winds flow across the forest floor. From micro-topographical differences appearing in a narrow area, the strong wind strongly disturbs the accumulated litters on the forest floor. The purpose of this study is to understand Rs characteristics at two sites where the litter accumulation is modified by wind. Accumulated litter, SOMC, Ts, soil moisture content (SMC), and Rs rate measurements were taken at Mt. Jeombong, from a slope and an adjacent ridge site, to use data analysis to determine the relationship between each environmental factor and the Rs.

\section{Methods and materials Site description}

The research site is a forest that is located at $786 \mathrm{~m}$ above sea level, southwest of Mt. Jeombong in Girin-myeon, Inje-gun, Kangweon-do $\left(38^{\circ} 02^{\prime} 16.5^{\prime \prime} \mathrm{N}, 128^{\circ} 28^{\prime} 08.5^{\prime \prime} \mathrm{E}\right)$.

The mean temperatures of January and August, the coldest and warmest months, are $-4.8{ }^{\circ} \mathrm{C}$ and $16.6{ }^{\circ} \mathrm{C}$, respectively. The average rainfall is about $1135.7 \mathrm{~mm}$, of which over $70 \%$ falls between June and September, with a relative humidity of $71 \%$ and an average evaporation of $1114 \mathrm{~mm}$.

The study area is dominated by high quality brown soils, which are typical temperate deciduous forest soils. The litter degradation is comparatively rapid. The organic matter of the forest floor is completely degraded and has 
mixed with mineral soil for many years such that the effective soil depth is deep and the material circulation is faster than that of coniferous forests (Kim et al. 2011).

The forest has been transformed from a pine forest into a deciduous broad-leaved forest, which is a common process in the studied area. The dominant tree species in the area are Quercus mongolica and Carpinus cordata, with Tilia amurensis and others appearing sporadically (Jin et al. 2002). It also consists of Pinus densiflora, for which the diameter of $3 \sim 4$ individuals measures $40 \sim 50 \mathrm{~cm}$, while the composition of the majority of trees mostly consists of trees with a diameter of $20 \sim 40 \mathrm{~cm}$. The ridge area is a gentle terrain with a slight southeastern slope. However, the southern slope is steeply inclined, at about $24^{\circ}$, and is exposed to strong winds from Winter to spring, during which the canopy is open, so almost all of the accumulated litter on the slope is restored to the ridge area.

\section{Soil respiration}

Rs was measured once per month from April or May when the snow and soil melts on the surface to October when the soil is frozen. Rs was collected by the closed chamber method (Lee 2018), and it was composed mainly two parts of collar and chamber cap. The inner diameter of the collar was $16 \mathrm{~cm}$, it was $15 \mathrm{~cm}$ in height, and it was made of an acrylic material. The chamber cap was installed with a $\mathrm{CO}_{2}$ sensor (GMP343, Vaisala, Finland) at the top of the interior. Six collars were installed at each site, and each collar was fixed by inserting them $5 \mathrm{~cm}$ deep into the soil.

To obtain the Rs, the chamber cap was attached to the top of the collar. When the chamber cap was installed onto the collar, the $\mathrm{CO}_{2}$ concentration in the closed space between the ground and the chamber cap increased over time. The increasing rate of the $\mathrm{CO}_{2}$ concentration was used to calculate Rs, accounting for several parameters such as air temperature, atmospheric air pressure, and closed chamber volume.

The Rs was calculated using the following equation:

$R_{\mathrm{S}}\left(\mathrm{mg} \mathrm{CO} \mathrm{CO}^{-2} \mathrm{~h}^{-1}\right)=a \cdot \rho \cdot V \cdot S^{-1}$.

where $a$ is the increasing rate of the $\mathrm{CO}_{2}\left(\mathrm{ppm} \mathrm{min}{ }^{-1}\right)$; $\rho$ is the $\mathrm{CO}_{2}$ density $\left(\mathrm{mg} \mathrm{m}^{-3}\right) ; V$ is the collar volume $\left(\mathrm{m}^{3}\right)$; and $S$ is the soil area $\left(\mathrm{m}^{2}\right)$.

\section{Environmental factors}

To obtain the accumulation rate of soil organic matter, we measured the organic matter content of the soil up to a $5 \mathrm{~cm}$ depth, and measured the accumulated litter of three sites at the beginning of the canopy. Litter was collected using a $30 \mathrm{~cm} \times 30 \mathrm{~cm}$ square, and the soil was sampled using a soil sample tube $(\phi=5 \mathrm{~cm}$, height $=$ $5.1 \mathrm{~cm}$ ) with a depth of $5 \mathrm{~cm}$. The litter and the soil were dried for $48 \mathrm{~h}$ in a dry oven at $80{ }^{\circ} \mathrm{C}$ and were then weighed. The soil was sieved with a $2 \mathrm{~mm}$ sieve, and a crucible with only a certain amount of soil below $2 \mathrm{~mm}$ was burned in an ignitor at $550{ }^{\circ} \mathrm{C}$ for $4 \mathrm{~h}$. The Ts and SMC were also collected from three sites around the collar measured for Rs and were measured and averaged when the Rs was collected.

\section{Results and discussion}

\section{Soil temperature}

As shown in Fig. 1, the Ts has risen from spring to the lowest value in October or November, when the peak is reached during the summer months of July and August showing a clear seasonal variation pattern. This seasonal change in Ts is a common seasonal change in Monsoon Asia.

Many studies in these areas have reported distinct seasonal changes in Ts and suggest seasonal changes in Ts as a major factor affecting seasonal changes in Rs (Meentemeyer 1984; Jeong et al. 2017; Eom et al. 2018). Regardless of the micro-topographical differences, seasonal changes in Rs show a clear seasonal variation regardless of the measurement year.

On the other hand, the mean Ts calculated by the measured data was $15.5^{\circ} \mathrm{C}$ on the ridge site, and $16.2{ }^{\circ} \mathrm{C}$ on the southern slope site, which was higher than normal by about $0.69{ }^{\circ} \mathrm{C}$. This slightly elevated temperature of the southern slope site was due to the measured values for May to July of 2013, a year which was characterized by very low precipitation and very dry conditions throughout East Asia. It seems that such a drying environment affected the rising of Ts in the southern slope site. There was low difference between the two sites except for this period, indicating that it did not significantly affect Rs. However, we should pay attention to the interpretation of the significant difference in Ts between May and July, the first half of summer of 2013.

\section{Soil moisture content}

Seasonal changes in SMC showed very dynamic variation (Fig. 2). Compared to the seasonal changes of Ts, it showed a tendency of change that did not show the clear seasonal change. However, even in this tendency, there was a pattern in which SMC was high and low. First, the period of high SMC is from June 2011 to July 2012, and the lowest period is from August 2012 to October 2013. SMC of ridge site and southern slope site were different in these two periods.

SMC is influenced by various factors such as possible evapotranspiration, precipitation, and plant absorption (Xu et al. 2004; Jeong et al. 2017). When the precipitation occurs, the SMC increases sharply. However, until the next precipitation, it gradually decreases due to the floor evaporation and vegetation catching, and proceeds to the dry state. However, if precipitation occurs again, it 


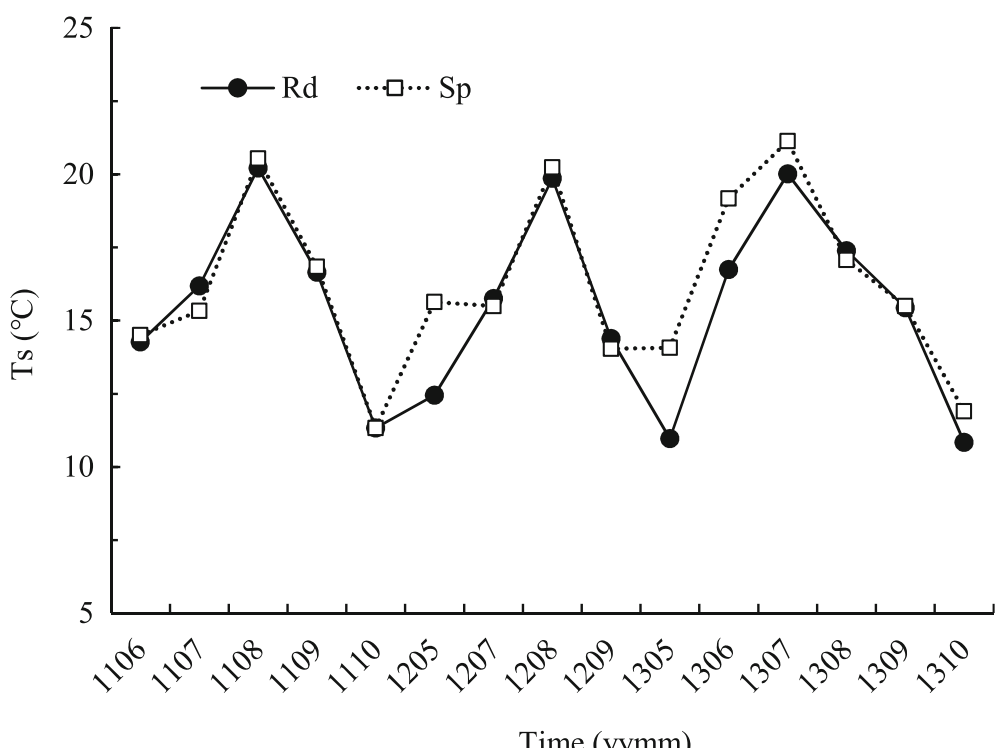

Fig. 1 Seasonal changes of soil temperature in ridge (Rd) and southern slope (Sp) plots in Quercus mongolica forest in Mt. Jeombong

increases to the maximum field water capacity level in proportion to precipitation. Figure 2 also reflects this variation. However, the fluctuation pattern of SMC is clearly shown in the southern slope site, it is not clear in the ridge site.

Overall, the SMC of the southern slope site in the first half of the high SMC period showed a rough change to $21.6 \%, 16.0 \%$, and $28.5 \%$ in August, September, and October 2011, respectively. However, at the same time, the ridge site showed a somewhat lower change of $26.8 \%, 19.4 \%$, and $23.8 \%$. This rough change pattern was not seen in 2013, under extremely dry conditions, and the difference in SMC between the ridge site and the southern slope site was not significant.

This sudden change of SMC at the southern slope site is very poor in the litter layer accumulated on the soil surface, so the water immediately flows into the soil at the time of precipitation and raises the SMC to the maximum field water capacity level. It seems that the SMC is sharply reduced because the water used to absorb the plant is only stored in the soil. However, these explanations need to be proven by additional experimental observations such as for the correlation between litter, precipitation, and water storage (Xu et al. 2004).

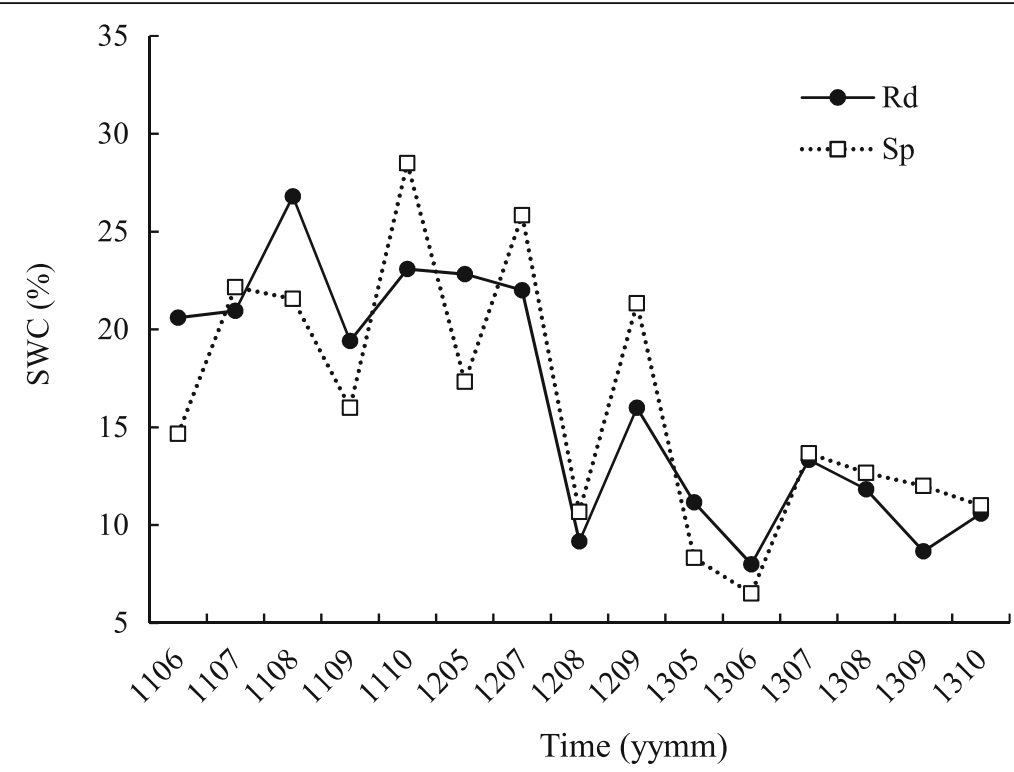

Fig. 2 Seasonal variation of soil water content (SWC) on ridge and southern slope in Quercus mongolica forest in Mt. Jeombong 


\section{Soil respiration and environmental factors}

Rs increased gradually from the April or May of the measurement year, peaked in July and August in summer, and then declined in October or November when the measurement was completed (Fig. 3). These seasonal changes in Rs are closely related to changes in Ts. The correlation between Ts and Rs was relatively high, as Fig. 4a and Fig. 4b. In general, the seasonal changes of the Ts are significant and affect soil respiration in various temperate ecosystems (Meentemeyer 1984; Kishimoto-Mo et al. 2015; Jeong et al. 2017; Eom et al. 2018). However, the seasonal variation patterns of these soil respirations are different at two sites. In ridge site, it was changed with the large range between the lowest and the highest values.

The lowest Rs in the ridge site during the measurement period was $174.50 \mathrm{mg} \mathrm{CO} \mathrm{m}^{-2} \mathrm{~h}^{-1}$ in May 2012, and $118.0 \mathrm{mg} \mathrm{CO} \mathrm{m}^{-2} \mathrm{~h}^{-1}$ in November 2011, in the southern slope site. The highest Rs measurements were $1077.2 \mathrm{mg} \mathrm{CO} \mathrm{m}^{-2} \mathrm{~h}^{-1}$ and $639.7 \mathrm{mg} \mathrm{CO}_{2} \mathrm{~m}^{-2} \mathrm{~h}^{-1}$, in August 2018, for both ridge and southern slope sites, respectively. As can be seen from these data, the maximum and minimum widths of Rs were much larger in the southern slope site than in the ridge site. The ranges of maximum and minimum values of $R s$ were $902.8 \mathrm{mg} \mathrm{CO} \mathrm{CO}_{2} \mathrm{~m}^{-1}$ in the ridge site and $511.7 \mathrm{mg} \mathrm{CO} \mathrm{m}^{-2} \mathrm{~h}^{-1}$ in the southern slope site. This variation depends on the magnitude of the potential of maximum Rs, which means that the ridge site has the potential to reach a much higher Rs value than the southern slope site.
As a result, it can be seen that the ridge site has a larger potential of soil respiration than the southern slope site. As can be seen in this study, the high potential of soil respiration in these ridge sites is attributed to environmental factors other than soil temperature (Fig. 2).

Among the environmental factors we measured, there was no significant difference in Ts between two sites, and SMC and SOMC showed specific differences at two sites. Here, SMC is considered to have the best range for soil respiration (Doran et al. 1990; Wang et al. 2006).

From this analysis, in the year 2012, when the highest Rs value was measured, was the most suitable SMC condition for Rs compared to other measurement years. In 2011, SMC remained extremely high due to high rainfall. On the other hand, in 2013, soil dryness could be the cause of Rs deterioration due to much lower precipitation than normal. However, when comparing extremely high to extremely low SMCs, too high SMC seems to suppress Rs more than extreme dryness (Suh et al. 2009). It is also considered that the SMC condition does not cause significant decrease of soil respiration in both sites. Consequently, SMC is an important factor affecting the rate of Rs during the summer, when Rs is not restricted by Ts.

On the other hand, the difference of Rs between slopes was much higher in August and September, when Ts was higher, than in May and October, which had lower Ts (Fig. 5). This tendency was the same during the 3 years of measurement, although there were some differences depending on the measurement year. In the relationship analysis between the $\mathrm{Ts}$ and the slope

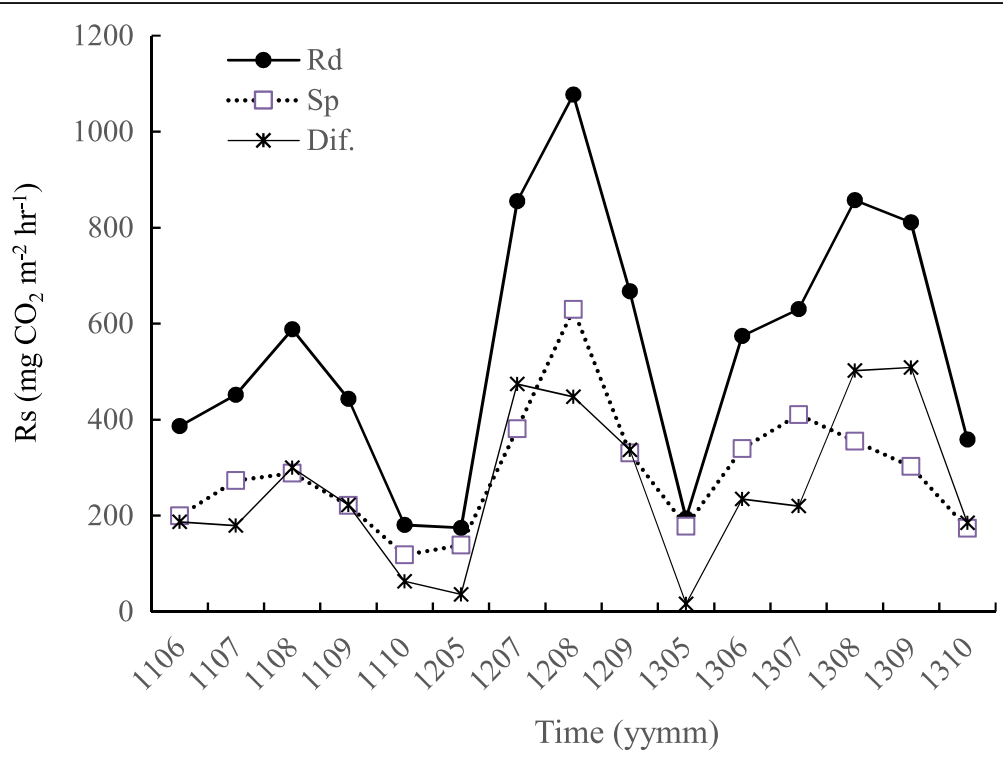

Fig. 3 Seasonal changes and difference (Rs) of soil respiration (Rs) and its difference in ridge (Rd) and southern slope (Sp) sites in Quercus mongolica forest in Mt. Jeombong 

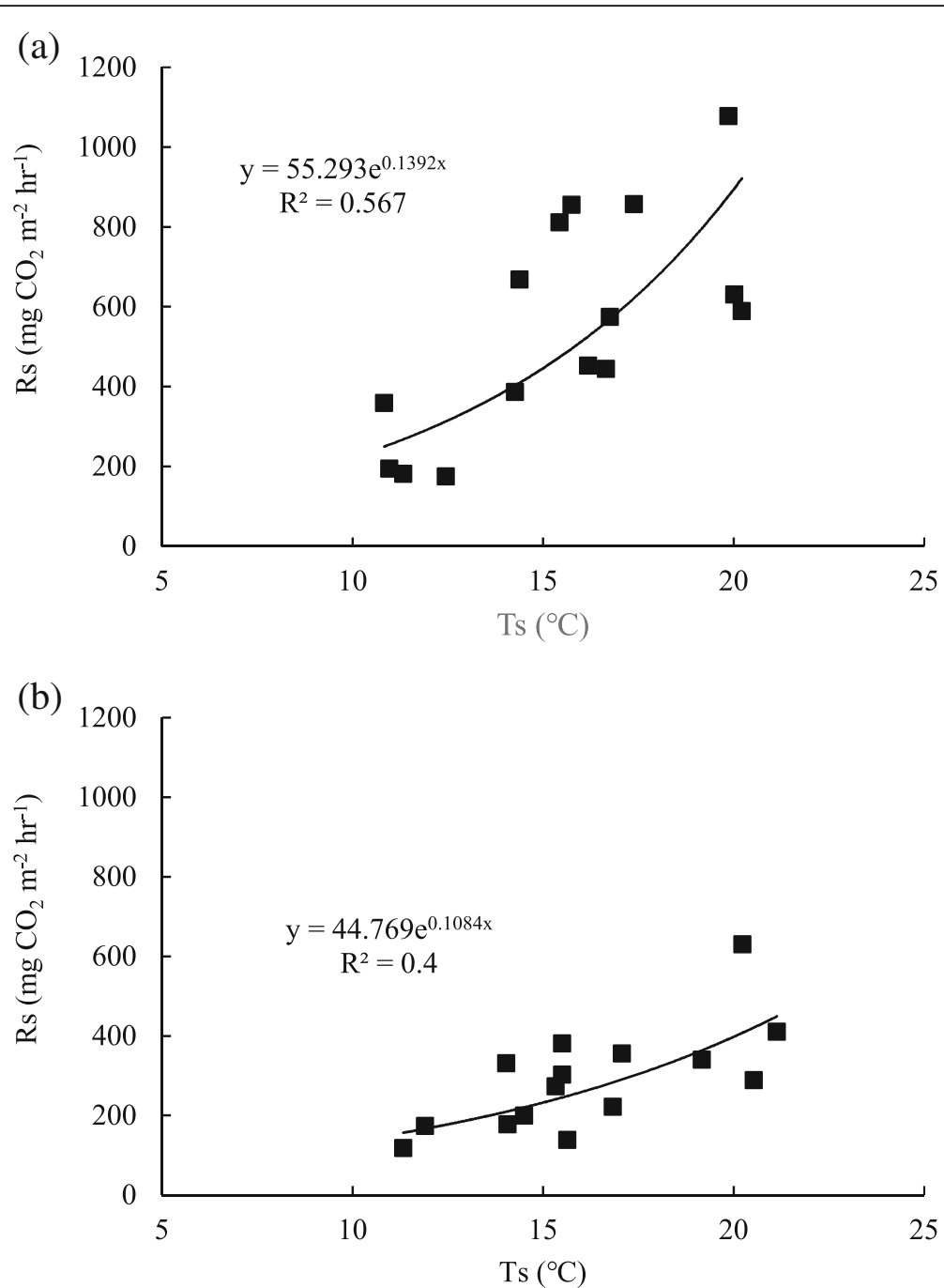

Fig. 4 Relationships between soil respiration (Rs) and soil temperature (Ts) in ridge (a) and southern slop (b) in Quercus mongolica forest in Mt. Jeombong

difference between the slopes, the correlation coefficient was 0.16 , which is lower than that of the slope. However, the slope difference tends to increase as the temperature increases, and as the SMC increases, the slope difference between Rs tends to decrease (Fig. 6).

The average Rs for the two sites, excepting the period not measured in Winter, were $550.1 \mathrm{mg} \mathrm{CO}_{2} \mathrm{~m}^{-2} \mathrm{~h}^{-1}$ at the ridge site and $289.4 \mathrm{mg} \mathrm{CO}_{2} \mathrm{~m}^{-2} \mathrm{~h}^{-1}$ at the southern slope site, which is a difference of $52.6 \%$. The difference in the Rs at these two sites seems to be due to the difference in SOMC and the amount of litter accumulated on the soil surface. As shown in Fig. 6, SOMC in the soil depth range of $0 \sim 5 \mathrm{~cm}$ and the accumulated litter of the soil surface were $874 \mathrm{~g} \mathrm{~m}^{-2}$ and $23.3 \%$ at the ridge site, $396 \mathrm{~g} \mathrm{~m}^{-2}$ and $19.9 \%$. Generally, in a temperate deciduous broad-leaved forest, litters are largely supplied to the surface with leaves that are removed from the canopy.
These litters are distributed widely from the high canopy position, depending on the strength and direction of the wind. Generally, the litters accumulated on the ground will be decomposed by micro-organisms on the ground yearly, unless disturbed.

However, the opening of the canopy resulting from the canopy leaf dropout strengthens the intensity of the wind blowing on the soil surface, thereby causing the litter to move between autumn to spring. The movement of these litters occurs especially strongly in spring, when the litter is very dry, compared to that in Winter, when the litter is covered by snow.

In this study, spatial variation was generated on the soil surface of certain areas, such as where the initially accumulated litter is remarkably lost or where the litter which is lost is significantly larger than the amount of initially accumulated litter. 


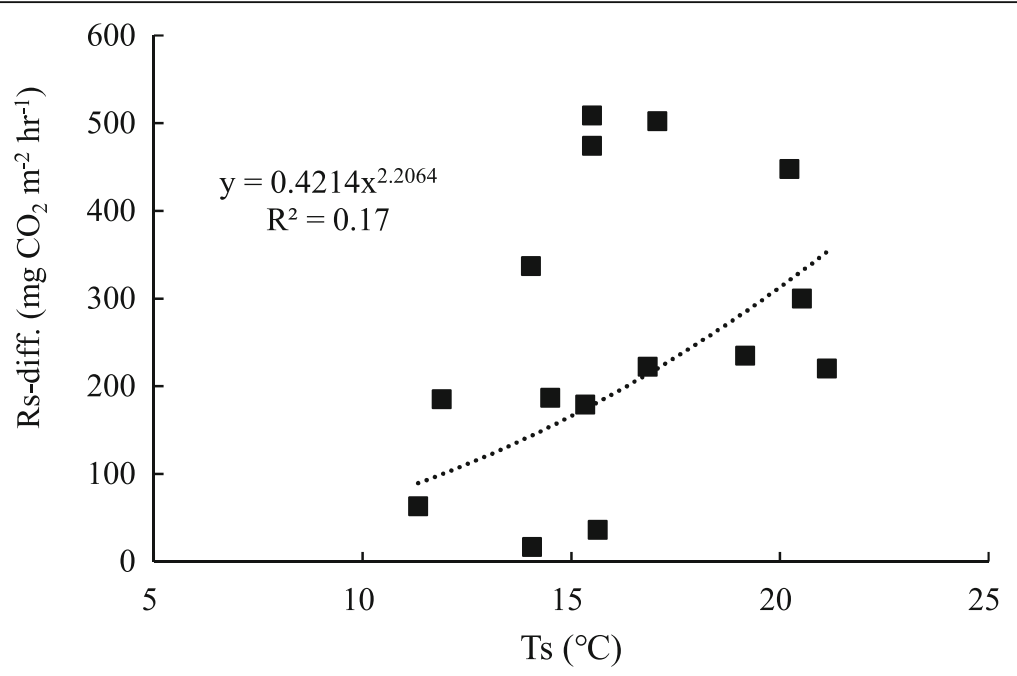

Fig. 5 Relationship between difference (ridge-southern slope) of soil respiration and soil temperature in Quercus mongolica forest in Mt. Jeombong

As a result, it can be concluded that various physiochemical environmental changes, due to the micro-geographical difference of the slope, and the change of the community structure, due to the plant season, occur and the complex combination of Rs resulting therefrom affects Rs (Epron et al. 2006). The ecology, soil properties, Ts, SMC, SOMC, and so on are not disconnected environmental elements, but instead relate to each other, changing the influence of each other to create various combinations of environmental conditions (Zhu et al. 2002). Rs is a component of the ecosystem carbon cycle associated with a combination of such diverse environmental factors.

\section{Conclusion}

In the Q. mongolica forest of Mt. Jeombong, Rs, Ts, $\mathrm{SMC}$, litter layer, and SOMC were measured in ridge and southern slope sites, which have two different results where the surface litter layers were disturbed by strong winds. The southern slope site shows that the litter layer formed in autumn due to strong winds has almost disappeared, while in the ridge site it has become thick due to the transfer of litter from the southern slope site.

The Rs measured at both sites showed a seasonal variation pattern that was interrelated with the seasonal Ts change (Figs. 1, 3, and 4). On the other hand, SMCs

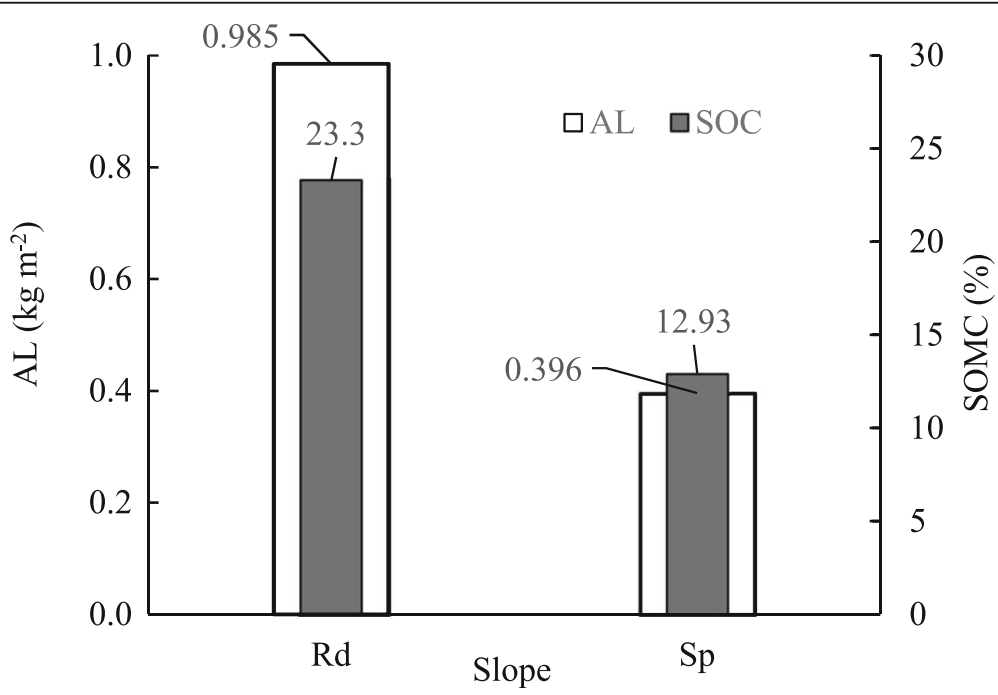

Fig. 6 Accumulated litter (AL) and soil organic matter content (SOMC) in ridge and southern slope sites in Quercus mongolica forest in Mt. Jeombong. The numbers in the graph indicate the amount of accumulated letter and soil organic matter content, respectively 
were divided into very high and low periods, and the range of change was larger in the southern slope site than in the ridge site. The difference in the Rs values between the two sites was the highest, while the SMC was measured at about $15 \%$ and at the higher temperature (Figs. 2 and 3).

The mean Rs was $550.1 \mathrm{mg} \mathrm{CO} \mathrm{m}^{-2} \mathrm{~h}^{-1}$ at the ridge site, while at the southern slope site, it was $289.4 \mathrm{mg} \mathrm{CO} \mathrm{Cm}^{-2} \mathrm{~h}^{-1}$, which is a difference of about $52.6 \%$. The difference in the Rs at these two sites seems to be due to the difference in the amount of litter accumulated on the soil surface. As shown in Fig. 6, SOMC at the depth range of $0 \sim 5 \mathrm{~cm}$ and the litter accumulation of the soil surface were $874 \mathrm{~g} \mathrm{~m}^{-2}$ and $23.3 \%$ at the ridge site and $396 \mathrm{~g} \mathrm{~m}^{-2}$ and $19.9 \%$ at the southern slope site.

As a result, the litter layer supplied to the soil surface is disturbed due to the micro-topographical difference as a slope and the change of the community structure due to the plant season, causing the heterogeneity of the litter layer development, which affects SMC and Rs. Therefore, it is necessary to introduce and understand these micro-topographical features and mechanisms when quantifying the Rs of ecosystems and analyzing their characteristics (Kang et al. 2003).

\section{Abbreviations}

a: Rate of increase of $\mathrm{CO}_{2}$; Rs: Soil respiration; S: Soil area; SMC: Soil moisture content; SOMC: Soil organic content; Ts: Soil temperature; V: Collar volume; p: $\mathrm{CO}_{2}$ density

\section{Acknowledgements}

Not applicable

\section{Funding}

This research was supported by the National Research Foundation of Korea (NRF) funded by the Ministry of Science, ICT and Future Planning (NRF2016M3C1B6928005).

\section{Availability of data and materials}

Not applicable

\section{Authors' contributions}

The author conceived the study, collected the data, interpreted the results, and wrote the manuscript.

\section{Ethics approval and consent to participate}

Not applicable

\section{Consent for publication}

Not applicable

\section{Competing interests}

The author declares that he/she has no competing interests.

\section{Publisher's Note}

Springer Nature remains neutral with regard to jurisdictional claims in published maps and institutional affiliations.
Received: 17 October 2018 Accepted: 1 November 2018

Published online: 20 November 2018

\section{References}

Chae N. Annual variation of soil respiration and precipitation in a temperate forest (Quercus serrata and Carpinus laxiflora) under east Asian monsoon climate. J Plant Biol. 2011:54:101-11.

Davidson EA, Belk E, Boon RD. Soil water content and temperature as independent or confounded factors controlling soil respiration in a temperature mixed hardwood forest. Glob Chang Biol. 1998;4:217-27.

Doran J, Mielke L, Power J. Microbial activity as regulated by soil water-filled pore space. In: Transactions 14th International Congress of Soil Science. International Society of Soil Sci; 1990. p. 94-9.

Eom JY, Jeong SH, Chun JH, Lee JH, Lee JS. Long-term characteristics of soil respiration in a Korean cool-temperate deciduous forest in a monsoon climate. Anim Cells Syst. 2018;22:2.

Epron D, Bosc A, Bonal D, Freycon V. Spatial variation of soil respiration across a topographic gradient in a tropical rain forest in French Guiana. 2006;22:56574.

Jeong SH, Eom JY, Lee JH, Lee JS. Effect of rainfall events on soil carbon flux in mountain pastures. J Ecol Environ. 2017;41:37.

Jeong SH, Eom JY, Park JY, Lee JH, Lee JS. Characteristics of accumulated soil carbon and soil respiration in temperate deciduous forest and alpine pastureland. J Ecol Environ. 2018:42:3.

Jin GZ, Yan T, Kim JH. The interpretation of community structure for the natural deciduous forest of Mt. Chumbong classified by TWINSPAN. J Korean For Soc. 2002;91:523-34.

Joo SJ, Park SU, Park MS, Lee CS. Estimation of soil respiration using automated chamber systems in an oak (Quercus mongolica) forest at the Nam-San site in Seoul, Korea. J Sci Total Environ. 2012;416:400-9.

Kang SK, Doh SY, Lee DS, Lee DW, Jin VL, Kimball JS. Topographic climatic controls on soil respiration in six temperate mixed-hardwood forest slopes, Korea. Glob Chang Biol. 2003;9:1427-37.

Kim GS, Song HK, Lee CH, Cho HJ, Lee CS. Ecological comparison of Mongolian oak (Quercus mongolica Fisch) community between Mt. Nam and Mt. Jeombong as a Long Term Ecological Research (LTER) site. J Ecol Environ. 2011:341:75-85.

Kishimoto-Mo A, Yonemura S, Uchida M, Kondo M, Murayama S, Koizumi H. Contribution of soil moisture to seasonal and annual variations of soil $\mathrm{CO} 2$ efflux in a humid cool-temperate oak-birch forest in Central Japan. Ecol Res. 2015;30:311-25.

Lee JS. Relationship of root biomass and soil respiration in a stand of deciduous broadleaved trees. - a case study in a maple tree. J Ecol Environ. 2018;42 (in press).

Liu X, Wan BS, Hui D, Luo Y. Response of soil $\mathrm{CO}_{2}$ efflux to water manipulation in a tallgrass prairie ecosystem. Plant Soil. 2002;240:213-23.

Lloyd J, Taylor JA. On the temperature dependence of soil respiration. Funct Ecol. 1994:8:315-23.

Luo $\mathrm{Y}$, Jackson CB, Mooney HA. Elevated $\mathrm{CO}_{2}$ increase belowground respiration in California grasslands. Oecologia. 1996;108:130-7.

Maier CA, Kress LW. Soil $\mathrm{CO}_{2}$ evolution and root respiration in 11 year-old loblolly pine (Pinus taeda) plantations ad affected by misture and nutrient availability. Can J For Res. 2000;30:347-59.

Meentemeyer V. The geography of organic decomposition rates. Ann Assoc Am Geogr. 1984;74:551-60.

Ohashi M, Gyokusen K. Temporal change in spatial variability of soil respiration on a slope of Japanese cedar (Cryptomeria japonica D. Don) forest. Soil Biol Biochem. 2007:39:1130-8.

Raich JW, Potter CS. Global patterns of carbon dioxide emission from soil. Global Biochem Cycle. 1995:9:23-36.

Raich JW, Schlesinger WH. The global carbon dioxide flux in soil respiration and its relationship to vegetation and climate. Tellus. 1992;44:81-99.

Raich JW, Tufekcloglu A. Vegetation and soil respiration: correlations and controls. Biogeochem. 2000;48:71-90.

Schlesinger WH. Carbon balance in terrestrial detritus. Annu Rev Ecol Evol Syst. 1977;:8:51-81

Singh JS, Gupta SR. Plant decomposition and soil respiration in terrestrial ecosystems. Bot Rev. 1977:43:449-529.

Son YH, Kim HW. Soil respiration in Pinus rigid and Larix leptolepis plantation. J Korea Forest Soci. 1996;85(3):469-505. 
Suh SU, Lee EH, Lee JS. Temperature and moisture sensitivities of $\mathrm{CO}_{2}$ efflux from lowland and alpine meadow soils. J Plant Ecol. 2009;2(4):225-31.

Wang C, Yang J, Zhang Q. Soil respiration in six temperate forests in China. Glob Change Biol. 2006;12:2103-14.

Xu L, Baldocchi DD, Tang J. How soil moisture, rain pulses, and growth alter the response of ecosystem respiration to temperature. Global Biogeochem Cycle. 2004;18:1029-35

Zhu J, Liu J, Zhu Q. Hydro-ecological functions of forest litter layers. J Beijing For Univ. 2002;24:30-4.

Ready to submit your research? Choose BMC and benefit from:

- fast, convenient online submission

- thorough peer review by experienced researchers in your field

- rapid publication on acceptance

- support for research data, including large and complex data types

- gold Open Access which fosters wider collaboration and increased citations

- maximum visibility for your research: over $100 \mathrm{M}$ website views per year

At BMC, research is always in progress.

Learn more biomedcentral.com/submissions 